Rękas M., Tax policy tools as an element of pro-family policy in France and in Germany - recommendations for Poland, „Ekonomia i Prawo. Economics and Law.”, Polszakiewicz B., Boehlke J. (ed.), Vol. 14, No. 1/2015, pp. 7-18. DOI: http://dx.doi.org/10.12775/EiP.2015.001.

\title{
TAX POLICY TOOLS AS AN ELEMENT OF PRO-FAMILY POLICY IN FRANCE AND IN GERMANY - RECOMMENDATIONS FOR POLAND
}

\author{
SUMMARY
}

The paper focuses on tools of tax policy used as an element of a pro-family policy in France and in Germany. The author intends to prove, using France as an example, that properly developed tax system may stimulate the fertility rate rise. Formulated recommendations for Poland are followed by a clue that effectiveness of the tax preferential conditions is high but only when they are an element of a coherent family promoting policy. Taxes used to promote the pro-family policy but separated from other policies are not an effective way to increase in the fertility rate.

The paper also includes comparative analysis of statistical data of fiscal duties imposed on incomes of families and incomes of singles. It enabled to divide analyzed countries into groups based on diversified levels of provided aid and to compare relations to the fertility rate. In the final part of the paper the author comments on the proposal of modification of tax reliefs in Poland proposed by the pro-family program of the President of the Republic of Poland in May 2013.

Keywords: fertility rate, tax policy, pro-family policy

JEL Classification: E24, H31, J16, J21, O52

* Magdalena Rękas, Wroclaw University of Economics, Faculty of Economics, Management and Tourism, Department of Economics and Economic Policy, ul. Nowowiejska 3, 58-500 Jelenia, phone: +48 7575383 70, e-mail: magdalena.rekas@ue.wroc.pl. 


\section{INTRODUCTION}

In the first decade of the twenty first century negative demographic phenomena have started to grow up. Consequently, situation is tough in many economies including the European Union member countries. A decrease in the fertility rate and ageing of the society cause a series of negative social and economic phenomena. In many European Union member countries the fertility rate fell down far below the simple replacement rate (demographic renewal) which means substantial deficiency of work force in the future which is one of crucial factors of the economic growth. It will also cause a collapse of the social insurance system etc. Therefore, facing the situation a lot of countries have applied a wider and wider range of economic policy tools to promote families.

Much pressure is put to tax preferential conditions, the most frequently 'inbuilt' into the income tax system. They are an important instrument which enables to soften family's fiscal duties since a family suffers from high costs generated by children. Analysis regarding justice of taxation recommend different privileges for families to compensate their loss caused by taxation compared to tax payers, who have no children ${ }^{1}$.

The goal of the paper is presentation of tax tools applied as an element of the pro-family policy implemented in Germany and in France. The aforementioned countries have been selected for needs of the analysis on the basis of opposite effects of implemented tax policies which could be a warning for Poland that simple transfer of samples from other EU countries does not have to result in positive effects, in particular, when the pro-family policy approach is not a complex one. To perform the goal also statistical data was analyzed reflecting level of fiscal duties of a family with two children and a single; it enabled to prove serious differences between family-oriented tax policies in different EU countries. The final part of the paper contains an assessment of tax solutions presented in the pro-family program of the Polish President dated May 2013.

${ }^{1}$ M. Rękas, Taxation as an instrument of family policy: effects for women's employment, [in:] T. Bernat (ed.), Transformations in Business Eं Economics, Vilnus 2011, Vol. 10, No. 2A(23A), p. 304. 


\section{PRO-FAMILY POLICY AND ITS INSTRUMENTS}

Contemporary democratic countries run their pro-family policies proposing certain aid for the basic social cell, which is a guarantor of social and economic development in every country. Simultaneously, in the face of the demographic crisis in Europe, the pro-family policy has become economic necessity and consequently, the countries have been increasing level of their expenses on pro-family goals in order to keep relevant age structure of the societies and at least, a simple re-production rate at 2,1 child per woman.

Defining the pro-family policy, A. Kurzynowski says this is: "general legal standards, actions and measures launched by a country in order to establish attractive conditions for a family enabling a family to establish its relations, develop properly and to perform its socially significant functions ${ }^{2}$.

A term frequently used at the time of public discussions that is "pro-family policy" is a common one, with use of which we can assess family-oriented social policy of a country. The term in question does not occur individually in the literature on the subject of the social policy. A family-oriented social policy of a country may be deemed to be a pro-family policy if it heads for clearly stipulated goals which a country intends to achieve in order to develop attractive conditions for a family and to satisfy social and cultural needs of a family ${ }^{3}$.

In the literature on the subject two types of pro-family policies are distinguished:

a. a policy clearly addressed to a family (explicite);

b. indirect policy (implicite).

Explicite family oriented policy means actions (e.g. programs) clear intent of which is achievement of particular goals regarding a family as an entire cell, or regarding roles of individual members of a family. Explicite family oriented policy may, e.g., include population-oriented policy, social benefits connected with children upbringing, benefits for working parents, health services for a mother and a child etc. In countries, which run direct family policy there are frequently set up special institutions at the government level, established to coordinate family-promoting actions. In turn, the implicite family oriented policy includes operations performed in other fields of a country's

2 A. Dragan, Sz. Woronowicz, Wybrane zagadnienia polityki prorodzinnej w niektórych państwach Unii Europejskiej, Biuro Analiz i Dokumentacji, Kancelaria Senatu, Warszawa 2013, p. 3.

3 B. Kłos, J. Szymańska, Polityka rodzinna - wybrane zagadnienia, Biuro Studiów i Ekspertyz Kancelaria Sejmu, No. 587, Warszawa 1997, p. 2. 
policies, which are designed to achieve goals not connected with a family in a direct way but which result in serious consequences for a family (unemployment preventing policy, tax policy) ${ }^{4}$.

The most frequently recognized object of a family-oriented policy is a family plus children (so called: nuclear family). Definition of a family must be "wide" enough in order to include variety of types, structures, roles and relations regarding (usually) at least one adult and a single child. Subject of interest of the pro-family policy is a marriage with children, parents with children (concubinages), one of parents with children (single father, single mother). Dependably on accepted main goal a pro-family policy may be addressed to all families with children or selected categories of families with children (e.g. poor families, multi-child families, incomplete families, families suffering from social pathologies).

A policy, which supports a family, is based on a series of tools and the most frequent ones are ${ }^{5}$ :

a. free of charge health services for a mother with a child;

b. social benefits (allowances, benefits, bonuses);

c. special leaves (maternity leave, parental leave, child care leave);

d. tax tools (tax relieves, tax credit);

e. flexible forms of employment;

f. special bonuses (e.g. housing benefits);

g. institutional care for a child (nursery, kindergarten, school, day-rooms);

h. special discount cards, e.g. for multi-child families.

It must be emphasized that in the European Union every country runs its pro-family policy oriented to accurately set out main goal (the most frequently - growth in the fertility) and other detailed goals. Below, there shall be analyzed selected solutions in the field of the fiscal policy of two European Union countries. The list shows a variety of pro-family actions. Further analysis will also show how seriously effects of similar solutions can be diversified, which proves that historical and cultural conditions have a great impact on family issues.

${ }^{4}$ Ibidem, p. 2-3.

${ }^{5}$ A. Dragan, Sz. Woronowicz, op. cit., p. 4. 


\section{FISCAL DUTIES IMPOSED ON FAMILIES AND SINGLES IN SELECTED EUROPEAN UNION COUNTRIES}

Fiscal duties affect a level of income which may be disposed by a household. Income is one of factors affecting a decision on having a child since from the economic point of view a child generates costs and the costs in question decrease the income which can be disposed. Therefore, it is a good idea to compare fiscal duties imposed on families and singles in order to find out how the EU countries compensate families having a child. Level of duties arising from the income tax (PIT) and social insurance premiums together with total costs of employment of an employee is presented in the table hereunder.

Analysis of the table 1 prove serious diverse of fiscal policy in relation to singles and families in European Union. The lowest fiscal duties rate in 2012 was observed in 2012 in Ireland (just 6,4\% of income is transferred to the country in form of the income tax and social insurance premiums), while the highest fiscal duties rate is observed in Greece and in Italy (43\% of a family's income). In turn, when it comes about singles the lowest taxation of incomes in 2012 characterized Luxemburg (just 13,4\% of income) and the highest one - Belgium - 56\% of income was transferred to the country in form of a tax and social insurance premiums.

Comparison of differences between duties of singles and duties of families " $2+2$ " is also crucial since it shows level of reduction on families' incomes in case of upbringing of 2 children. Apart from Luxemburg, where preferential tax rates are designed for singles and much higher rates are designed for families with 2 children (by 22,4 percentage point), all remaining examined countries apply varied tax preferential conditions for families with children in order to neutralize expenses related with upbringing of children.

Table 1. The level of fiscal burden*families and singles in selected EU countries in 2012

\begin{tabular}{|c|c|c|c|c|}
\hline \multirow{2}{*}{ COUNTRY } & $\begin{array}{c}\text { FISCAL DUTIES IMPOSED } \\
\text { ON INCOMES ** OF FAMILY } \\
- \text { MODEL: } 2+2(\%)\end{array}$ & $\begin{array}{c}\text { FISCAL DUTIES IM- } \\
\text { POSED ON INCOMES } \\
{ }^{* *} \text { OF SINGLES (\%) }\end{array}$ & $\begin{array}{c}\text { DIFFERENCE BETWEEN THE DUTIES } \\
\text { OF A SINGLE AND A FAMIIY WITH } \\
\text { CHILDREN (PERCENTAGE POINT) }\end{array}$ & $\begin{array}{c}\text { FERTILITY } \\
\text { RATE } \\
\text { IN } 2011\end{array}$ \\
\hline France & A & B & 34.9 & D \\
\hline Luxemburg & 15.3 & 50.2 & -22.4 & 2.0 \\
\hline Czech & 35.8 & 13.4 & 21.7 & 1.6 \\
\hline Ireland & 20.7 & 42.4 & 19.5 & 2.5 \\
\hline
\end{tabular}




\begin{tabular}{|c|c|c|c|c|}
\hline COUNTRY & $\begin{array}{l}\text { FISCAL DUTIES IMPOSED } \\
\text { ON INCOMES }{ }^{* *} \text { OF FAMILY } \\
\text { - MODEL: } 2+2(\%)\end{array}$ & $\begin{array}{l}\text { FISCAL DUTIES IM- } \\
\text { POSED ON INCOMES } \\
{ }^{\star *} \text { OF SINGLES }(\%)\end{array}$ & $\begin{array}{l}\text { DIFFERENCE BETWEEN THE DUTIES } \\
\text { OF A SINGLE AND A FAMILY WITH } \\
\text { CHILDREN (PERCENTAGE POINT) }\end{array}$ & $\begin{array}{l}\text { FERTILITY } \\
\text { RATE } \\
\text { IN } 2011\end{array}$ \\
\hline & A & B & $C=B-A$ & D \\
\hline Slovenia & 22.8 & 42.3 & 19.5 & 1.4 \\
\hline Hungary & 33.6 & 49.4 & 15.8 & 1.3 \\
\hline Germany & 34.2 & 49.8 & 15.6 & 1.3 \\
\hline Belgium & 41.3 & 56.0 & 14.7 & 1.8 \\
\hline Slovakia & 25.8 & 39.6 & 13.8 & 1.8 \\
\hline Poland & 29.6 & 35.4 & 5.8 & 1.3 \\
\hline Sweden & 37.5 & 43.2 & 5.7 & 1.9 \\
\hline Finland & 37.2 & 42.5 & 5.3 & 1.9 \\
\hline Great Britain & 27.9 & 33.1 & 5.2 & 2.0 \\
\hline Italy & 43.0 & 47.6 & 4.6 & 1.4 \\
\hline Spain & 37.9 & 41.4 & 3.5 & 1.4 \\
\hline Greece & 43.0 & 41.9 & -1.1 & 1.5 \\
\hline
\end{tabular}

* percentage which is paid (by tax payers) to the country on the basis of PIT tax and social insurance premiums compared to total costs of employment of an employee;

**income on the basis of an average salary in a particular country.

Source: The author's material developed on the grounds of a report by OECD - Taxing Wages $2013 \mathrm{http}: / / w w w . o e c d$. org/tax/tax-policy/taxingwages.htm (28.08.2013).

Analyzed countries may be divided into three groups:

a. Group 1 "aid for families, exceeding 20\%", countries: France, Czech, Ireland, Slovenia - are characterized by substantial aid provided to families with children. A difference, to the benefit of families, fluctuates from 34,9 percentage point in France to 19,5 percentage point in Slovenia.

b. Group 2 "aid for families, between 10-20\%": Hungary, Germany, Belgium, Slovakia that is countries of moderate aid for families with children. Taxation for this group of tax payers is lower by 15,8 percentage point in Hungary to 13,8 percentage point in Slovakia.

c. Group 3 "aid for families, not exceeding 10\%" includes Poland, Sweden, Finland, Great Britain, Italy and Spain. In these countries there is observed lower taxation on families' incomes (compared to singles) by 5,8 percentage point in Poland to 3,5 percentage point in Spain.

d. Group 4 "others" - already mentioned Luxemburg, which applies substantial taxation reliefs but they are designed for singles, and Greece, 
which applies a little - by 1,1 percentage point higher taxation rate for families compared to taxation rate designed for singles.

Fertility rates in EU countries in question are worth of being analyzed. Listing of countries and fertility rates shows serious differences when it comes about effectiveness of applied preferential fiscal duties on incomes. Three from among analyzed countries are close to achieve simple replacement rate (desired level 2,1) despite the fact they apply very opposite approach to the preferential treatment of families in the framework of the tax system. Therefore, there are France and Ireland from the group no. 1 that is two countries which apply tax preferential conditions but their "scale" is different (in France families' (fiscal) duties are by 34,9 percentage point lower when compared to duties of singles while in the Ireland the duties are lower by 19,5 percentage point) and there is Great Britain from the group no. 3, where the gap between taxation of families' incomes compared to taxation of singles equals just to 5,2 percentage point. It could mean that the afore mentioned countries apply very opposite model of support provided to families and they pay attention to other instruments of such a policy.

Poland belongs to the third group of countries which provide families with relatively low fiscal aid and having the fertility rate at the 1,3 level. Nevertheless, in the same group there are Sweden and Finland characterized by the fertility rate close to 2 . Again, it is confirmed that family promoting policies in these two countries are focused on non-fiscal instruments.

Nevertheless, in the face of a low fertility rate, implementation of mechanisms neutralizing fiscality in relation to tax payers having children is justified since incomes of families are reduced by expenses on children, and they are not incurred by singles.

\section{TAX POLICY TOOLS IN FRANCE AND IN GERMANY}

France and Germany are two EU countries which have substantially increased their expenses on pro-family policy in the last decade but effects are very unlike. In Germany expenses on pro-family policy has been tripled for the last 10 years. In 2011 the expenses in question posed 10,7\% of total social expenses (in Poland they pose just 4,2\% of total social expenses), but the fertility rate in Germany has been still falling down, while in France the expenses on pro-family policy posed $8,3 \%$ of total social expenses and the fer- 
tility rate has been growing up ${ }^{6}$. France is one of few countries with growing number of citizens. Comparative analysis shall be focused on instruments implemented in both of these countries.

The tax system in France is one of the most pro-family systems in the EU countries. It provides Frenchmen with a series of tax relieves and highly-developed social support system. There dominates horizontal re-distribution rule, that is from families not having children to those families, who have children, and more and more frequently - vertical re-distribution, which means intent to reduce life quality rate gap between families, who have the same number of children but their incomes are very different ${ }^{7}$.

However, the most significant fiscal instrument of the French pro-family policy is so called "family quotient" (quotient familial) and it means transfer of financial means in the framework of a group of families of the same incomes from families, which have no children. The family quotient depends on so called: "fiscal parts" calculated on the basis of number of members of family. Total family income to be taxed is an amount arising from real income divided by relevant number of "fiscal parts". Such an amount is basis for taxation acc. to relevant rates, and then it is multiplied by fiscal parts (the mechanism is similar to e.g. mutual taxation of spouses in Poland). As a result, the family quotation enables to pay much lower tax when a family is numerous (large $)^{8}$, since the quotation for a spouse with a single child equals to 2,5, while in case of three children it equals to 4 parts. In case of having a child by a single parent the quotation equals to 1,5 . Consequently and contrary to solutions implemented in Ireland, full families are promoted in France. Generally, giving birth to a third child in a family with average incomes means total release from the income tax. Additionally, in situation, when a disabled child is brought up, the family quotation may by increased by "half of the fiscal part" .

Other instruments of the fiscal policy in France are discounts related directly with costs incurred by parents on upbringing and education of a child. E.g. in 2011 it was possible to deduct all fees incurred to pay for child care beyond house from income (fees for kindergartens, stays in a day-care centers)

${ }^{6}$ ICRA Friedrich Ebert Stiftung, Wyzwania demograficzne Europy, Warszawa 2012.

7 PricewaterhousCoopers, International Assignment Services Taxation of Internatinal Assignees - France, 2010, p. 14.

${ }^{8}$ E.g., a family with two children, gaining the same income which is gained by a single, pays in France 5 times lower tax - compare: E. Matyszewska, Francja najmocniej wspiera rodziny z dzieckiem, „Gazeta Prawna” 23.10.2011, p. 11.

9 S. Cazain, M. Nicolas, Evolution des publics cibles de la politique familiale, „l'e-ssentiel”, Publication electronique de la Cnaf, No. 51/2006, p. 23. 
or in house, if the care was provided by an upbringing assistant - in amount of $50 \%$ of costs up to the 2.300 Euro/annually. It is also possible to deduct from the tax an amount, which is supposed to cover expenses on school - gymnasium (61 Euro annually), high school (153 EUR) and university $(183 \text { EUR })^{10}$.

Worth of attention is also a tax relief applied in France awarded to persons, who work at home - annual deduction from the tax in 2003 amounted to 3.700 EUR and starting from 2005 it amounts to 5.000 EUR. In opinion of certain labor market analytics increase in the relief in question resulted in immediate growth in number of parents, who individually take care for their small children, combining professional and private life ${ }^{11}$.

Germany - the second of analyzed countries. Starting from 80's. of the XX century the country has been characterized by a low fertility rate $(1,2$ - 1,4). Consequently, since 2004 the number of German citizens has been falling down. It resulted in necessity of modernization of a pro-family policy and extension of the policy like in France. Since 2002 a series of amendments of the tax system have been implemented. Presently, since 2012 parents of every child aged up to 18 are entitled to a tax credit (tax-free amount) 2184 Euro annually, and in case of joint settlement of spouses this makes the amount of 4.368 Euro per a child. Additionally, parents are entitled to a discount based on a provided child care, in amount accordingly - 1320 EUR for a single child and 2640 EUR in case of two children (in case of parents, who lodge a joint tax return). It means that the basic tax relief, which is a tax credit, for a family with a single child amounts to 7 thousand Euros annually ${ }^{12}$.

Moreover, the following expenses may be deducted from the tax:

a. education for children aged more than 18 (924 Euro annually per child),

b. child care, e.g. school-fee for kindergarten or private school, for children aged up to 14 , in amount of $2 / 3$ of actually incurred costs and up to amount of 4 thousand Euros per every child, provided that both of parents work, and in case when one of the parents works only, the discount is granted for child aged $3-6$.

c. In case of parents, who individually bring children up - for the care for a child aged up to 18 the discount amounts to 1308 Euro/year ${ }^{13}$.

${ }^{10}$ Inspector General for Tax, www.impots.gouv.fr (2.03.2012).

11 P. Szukalski, Publiczne wsparcie dla rodzin we wspótczesnej Francji, Warszawa 2010, www. kobieta.gov.pl., (25.08.2013).

12 A. Dragan, Sz. Woronowicz, op. cit., p. 4.

${ }^{13}$ Ibidem. 
Germans, following the France solutions, considered implementation of a "joint family taxation" and application of "fiscal parts" but finally the idea was rejected and there was proposed an increase in the amount of tax relief for a single child in amount of 8 thousand Euro from 2014. There was also proposed a tax relief for couples, who are not married and homosexual couples ${ }^{14}$.

Such expanded tax relieves make that the aid for families, who have children in France and in Germany, is several times higher compared to Poland. PricewaterhouseCoopers experts compared 25 countries of the European Union. A base for the calculations there was a working marriage, consisting of parents earning average salaries in a particular country with two children aged 2 and 5. It turned out that Poles may count on (averagely) 2,3 thousand PLN that is 2,6 percent of annual incomes while the mean in the Union equals to 5,5\%. When it comes about salaries parents in Bulgaria, Italy and Greece only are in worse situation. The highest amount of aid is provided to French citizens - equivalent of nearly 28,5 thousand PLN which poses $11,4 \%$ of French citizen's incomes. Other nations, which may count on similar aid are Fins and Germans (nearly 27 thousand PLN). In their case the benefits, discounts and tax relieves pose nearly $10 \%$ of their incomes ${ }^{15}$.

\section{CONCLUSIONS}

Pro-family programs are very cost generating and their effects are longterm ones. Nevertheless, countries fighting against unfavorable fertility rate make different efforts to stimulate the fertility. The tax solutions presented above applied in two EU countries prove there is no a one effective tax policy.

French tax solutions resulted in higher growth in the fertility rate but they were inbuilt into a developed pro-family policy and they are strictly connected with the employment policy. One of the French advantages in the field of pro-family policy is incredibly strong national child care system and popularization of flexible employment forms without which the fertility rate promoted by tax relieves only would not be so great. In turn, German model focused on taxes in order to stimulate the fertility rate failed because of no connection with other elements of the pro-family policy. No system of child

${ }^{14}$ S. Rabbe, Polityka rodzinna - model niemiecki instrumenty $i$ wyzwania, Fundacja Energia dla Europy, No. 4.11.2012, p. 3.

15 A. Zwoliński, Francuzi i Niemcy dostajq na dzieci 12 razy więcej od Polaków, http://www. money.pl/gospodarka/wiadomosci/artykul/dostajemy;na;dzieci;12;razy;mniej;niz;francuzi;i;niem cy,6,0,1314054.html (23.08.2013). 
care, which exists in France, makes that the fertility rate has been falling down despite expenses on the pro-family policy has been growing up. Moreover, developed one-side social benefits system and no programs focused on combination of family and professional life (dislike of German employers to hire German women because of problems with care for children) makes that the fertility rate in this country is at very low level that is 1,3 .

Polish tax system includes only two elements of pro-family character tax structures: child relief - in form of deduction from tax and a joint settlement of tax by individual parent with a child. Form of the present child tax relief (form of deduction from tax) makes that the higher number of children in a family the lower tax relief is. CenEa Foundation's analysis show that approx. $32 \%$ of tax payers, who have children, cannot use maximal deductions arising from number of children because of too low incomes gained by families. Rate of families in Poland, which have a chance to use the full amount of discount is relatively high but only in case of families with the only child $(76,1 \%)$ and it falls down as the number of children grows up. In case of families with two children the rate of parents, who may use the tax relief fully, equals to $67,6 \%$ and in case of higher number of children $-30,8 \%{ }^{16}$.

Modification of the tax relief valid from 1 January 2013 made that spouses, who have income exceeding 112 thousand PLN, will lose the tax relief if they have one child only. In other words it means that the most wealthy marriages with a one child, with gross incomes exceeding 10400 PLN, lost the right to the child tax relief this year. However, the families, whose incomes do not exceed the threshold referred to in the previous sentence, may be granted a support in amount of 92,69 PLN monthly while the poorest families with one child only receive the aid in amount of (up to) 115,00 PLN. The span is relatively low and the level of incomes very high.

Family support program presented by the Polish President in May 2013 and setting up of All-Poland Family Card assumes 44 operations intended to support a family and this is the first one complex pro-family program. Among proposed changes in the field of taxes there occurred liquidation of previous child relief in form of deduction from tax and implementation, similarly to Germany, tax credits based on number of children. This solution must be assessed to be a positive one since it would assure that every family, which pays an income tax, could benefit from total amount of the relief. Nevertheless, one should remember that despite the fact the solution in question is justified from point of view of support and neutralization of expenses on children up-

16 A. Bosak, Im więcej masz dzieci tym mniejsze ulgi, http://www.strefabiznesu. nowiny24.pl/ artykul/im-wiecej-masz-dzieci-tym-mniejsze-ulgi (20.08.2013). 
bringing, without other elements of the President's program the fertility rate will not grow up similarly like in case of Germany. Moreover, one may still have an impression that Poland still experiments with the pro-life policy. No stable pro-family system and its permanent changes do not promote a decision on having or increasing the number of children. We should hope that the President's family aid program will be implemented despite it is a cost generating element. Otherwise Poles will follow e.g. Romania, where the number of pensioners in 2013 exceeded the number of employees. It generates negative economic, cultural and social effects. Costs of liquidation of effects are frequently higher than costs of prevention of the demographic catastrophe by family aid programs.

\section{BIBLIOGRAPHY}

Bosak A., Im więcej masz dzieci tym mniejsze ulgi, http://www.strefabiznesu. nowiny24. $\mathrm{pl} /$ artykul/im-wiecej-masz-dzieci-tym-mniejsze-ulgi (20.08.2013).

Cazain S., Nicolas M., Evolution des publics cibles de la politique familiale, „l'e-ssentiel”, Publication electronique de la Cnaf, No. 51/2006.

Dragan A., Woronowicz Sz., Wybrane zagadnienia polityki prorodzinnej w niektórych pañstwach Unii Europejskiej, Biuro Analiz i Dokumentacji, Kancelaria Senatu, Warszawa 2013.

ICRA Friedrich Ebert Stiftung, Wyzwania demograficzne Europy, Warszawa 2012.

Inspector General for Tax, www.impots.gouv.fr (02.03.2012).

Kłos B., Szymańska J., Polityka rodzinna - wybrane zagadnienia, Biuro Studiów i Ekspertyz Kancelaria Sejmu, No. 587, Warszawa 1997.

Matyszewska E., Francja najmocniej wspiera rodziny z dzieckiem, „Gazeta Prawna” 23.12.2011.

PricewaterhousCoopers, International Assignment Services Taxation of Internatinal Assignees - France, 2010.

Rabbe S., Polityka rodzinna - model niemiecki instrumenty $i$ wyzwania, Fundacja Energia dla Europy, No. 4.11.2012.

Rękas M., Taxation as an instrument of family policy: effects for women's employment, [in:] Bernat T. (ed.), Transformations in Business E Economics, Vilnus 2011, Vol. 10, No. 2A(23A).

Szukalski P., Publiczne wsparcie dla rodzin we wspótczesnej Francji, Warszawa 2010, www.kobieta.gov.pl, (25.08.2013).

Zwoliński A., Francuzi i Niemcy dostaja na dzieci 12 razy więcej od Polaków, http:// www.money.pl/gospodarka/wiadomosci/artykul/dostajemy;na;dzieci;12;razy;mniej ;niz;francuzi;i;niemcy,6,0,1314054.html (23.08.2013). 